\title{
Efforts to Improve Science Learning Outcomes Through Model Problem Based Learning (PBL) Class VI SD Negeri Losari Kidul 02
}

\author{
Ujang Safii \\ SD Negeri Losari Kidul 02 \\ uzessyah@gmail.com
}

\section{Article History}

received 3/12/2020

revised 17/12/2020

accepted $31 / 12 / 2020$

\begin{abstract}
This Classroom Action Research is an effort to improve student learning outcomes on the magnetic properties of science subject content through themodel Problem Based Learning. This research was conducted on the sixth grade students of SD Negeri Losari Kidul 02. This research was motivated by the teacher not using learning models and media. The learning model used is too conventional and in teaching does not use media during the learning process. Student learning outcomes are still low, many students score below the KKM in science learning as measured by a test at the end of the lesson. This study uses Classroom Action Research (CAR) with steps consisting of planning, implementation, observation, and reflection in each cycle. This research was conducted in two cycles. In each cycle, learning activities are carried out by applying thelearning model Problem Based Learning. This research shows that students' learning outcomes in the matter of magnetic properties through themodel Problem Based Learning can increase. This increase can be seen from the results of classroom action research in cycles I and II. In the first cycle of students who completed KKM 70 as many as 58.7\% (10 people from 17 students). In cycle II, students who completed KKM 70 were $88.1 \%$ or 15 of 17 students. The conclusion obtained in this study is that the use oflearning models Problem Based Learning can improve learning outcomes in science learning material magnetic properties in class VI students of SD Negeri Losari Kidul 02.
\end{abstract}

Keywords: problem based learning, magnetic properties and learning outcomes

\begin{abstract}
Abstrak
Penelitian Tindakan Kelas ini merupakan upaya untuk meningkatkan hasil belajar peserta didik pada materi sifat-sifat magnet muatan pelajaran IPA melalui model pembelajaran Problem Based Learning. Penelitian ini dilaksanakan pada peserta didik kelas VI SD Negeri Losari Kidul 02. Penelitian ini dilatarbelakangi oleh guru tidak menggunakan model dan media pembelajaran. Penelitian ini menggunakan Penelitian Tindakan Kelas (PTK) dengan langkahlangkah yang terdiri dari perencanaan, pelaksanaan, observasi, dan refleksi pada setiap siklusnya. Penelitian ini dilaksanakan dalam dua siklus. Dalam tiap siklus dilaksanakan kegiatan pembelajaran dengan menerapkan model pembelajaran Problem Based Learning. Penelitian ini menunjukkan bahwa hasil belajar peserta didik dalam materi sifat-sifat magnet melalui model pembelajaran Problem Based Learning dapat meningkat. Peningkatan tersebut dapat dilihat dari hasil penelitian tindakan kelas pada siklus I dan II. Pada siklus I peserta didik yang tuntas KKM 70 sebanyak $58,7 \%$ (10 orang dari 17 peserta didik). Pada siklus II siwa yang tuntas KKM 70 sebanyak $88,1 \%$ atau 15 orang dari 17 peserta didik. Kesimpulan yang diperoleh dalam penelitian ini adalah bahwa penggunaan model pembelajaran Problem Based Learning dapat meningkatkan hasil belajar IPA materi sifat-sifat magnet pada peserta didik kelas VI SD Negeri Losari Kidul 02.
\end{abstract}

Kata kunci: problem based learning, sifat-sifat magnet dan hasil belajar

Social, Humanities, and Education Studies (SHEs): Conference Series p-ISSN 2620-9284 https://jurnal.uns.ac.id/shes 


\section{PENDAHULUAN}

Pada era pandemi covid19 seperti saat ini pembelajaran jarak jauh sangat penting dilaksanakan dengan perencanaan, pelaksanaan dan evaluasi yang baik. Dari bulan maret 2020 hingga oktober 2020 ini pemerintah masih mencanangkan program pembelajaran jarak jauh demi keselamatan peserta didik. Oleh karenanya peserta didik belajar melalui online/ daring (dalam jaringan) dipandu oleh Bapak/ Ibu guru dimana dia bersekolah sebelum pandemi covid19 terjadi.

Selama 5 bulan ini peneliti mendapati masukan dari peserta terkait pemahaman mereka tentang materi masih sangat minim saat pembelajaran jarak jauh saat ini. Kemudian guru juga melihat semangat peserta didik kurang begitu terlihat aktif selama pembelajaran jarak jauh dilihat dari rekap presensi kehadiran dan pengumpulan tugas setiap bulannya untuk laporan sasaran kinerja pegawai (SKP).

Jenjang pendidikan yang paling dasar di Indonesia adalah sekolah dasar. Sekolah dasar ditempuh dalam waktu 6 tahun, mulai dari kelas I sampai kelas VI. Salah satu pelajaran yang diajarkan di jenjang sekolah dasar adalah IPA. IPA merupakan sebuah ilmu pengetahuan yang mempelajari tentang gejala-gejala alam dan kebendaan yang sistematis yang tersusun secara teratur dan berlaku umum berupa kumpulan hasil observasi dan eksperimen.

Aspek-aspek pendidikan yaitu aspek kognitif, aspek afektif, dan aspek psikomotor. Aspek kognitif meliputi tujuan-tujuan belajar yang berhubungan dengan memanggil kembali pengetahuan dan pengembangan kemampuan intelektual dan keterampilan. Aspek afektif meliputi tujuan-tujuan belajar yang menjelaskan perubahan sikap, minat, nilai-nilai, dan pengembangan apresiasi serta penyesuaian. Aspek psikomotor meliputi tujuan-tujuan belajar yaitu berkaitan dengan ketrampilan (skill) peserta didik dalam bertindak berdasarkan pengalaman.

Masa Pandemi Corona Virus 19 (Covid-19) ini membuat proses pembelajaran yang biasanya dilaksanakan dengan tatap muka di depan kelas, tak dapat dilaksanakan lagi, hal ini karena adanya khawatiran makin menyebarnya Covid-19. Perlunya alternatif pembelajaran untuk menunjang kualitas pembelajaran yang baik demi keberlangsungan pendidikan putra dan puteri bangsa indonesia.

Pada observasi awal sebelum penerapan model Problem Based Learning (PBL), guru tidak menggunakan model dan media pembelajaran ketika mengajar di kelas, hasil belajar peserta didik masih banyak yang dibawah KKM dalam pembelajaran IPA yang diukur dengan tes pada akhir pembelajaran, peserta didik belum terlihat aktif dalam pembelajaran, guru kurang memotivasi peserta didik, guru kurang menguasai kelas, dan guru masih menerapkan metode ceramah.

Berdasarkan permasalahan tersebut di atas, dapat dikatakan bahwa hasil belajar IPA materi Sifat-sifat Magnet peserta didik kelas VI SD Negeri Losari Kidul 02 masih rendah sehingga perlu dilakukan tindakan untuk meningkatkan hasil belajar tersebut.

Untuk mengatasi masalah tersebut diperlukan model pembelajaran yang mampu mengatasi permasalahan itu. Maka dari itu peneliti akan menggunakan model pembelajaran Problem Based Learning (PBL) sebagai model pembelajaran yang bertujuan agar peserta didik lebih bisa meningkatkan hasil belajar dalam pembelajaran IPA.

Dari uraian di atas dapat dipahami bahwa yang terjadi pada peserta didik kelas VI SD Negeri Losari Kidul 02 adalah kurangnya nilai hasil belajar peserta didik karena penggunaan model pembelajaran yang kurang

tepat. Maka dari itu peneliti berharap dengan penggunaan model pembelajaran Problem Based Learning (PBL) dapat meningkatkan nilai hasil belajar peserta didik pada muatan pelajaran IPA 


\section{METODE}

Penelitian ini merupakan Penelitian Tindakan Kelas (PTK) yang dilaksanakan di kelas VI SD Negeri Losari Kidul 02 Tahun Pelajaran 2019/2020. Sekolah ini beralamat di Jalan Pusponegoro I Gg. Kemuning 108, Desa Losari Kidul Kecamatan Brebes Kabupaten Brebes. Adapun yang menjadi alasan penulis untuk memilih lokasi ini adalah bertepatan dengan tempat melaksanakan tugas sebagai guru kelas, sehingga dapat memberi kemudahan bagi penulis dalam melaksanakan penelitian ini. Waktu penelitian ini dilaksanakan pada Semester I Tahun Pelajaran 2019/2020. Prosedur penelitian dilakukan menggunakan model spiral dua siklus, dengan alur masingmasing meliputi perencanaan, pelaksanaan tindakan, observasi dan refleksi (Arikunto: 2013: 15)

\section{HASIL DAN PEMBAHASAN}

Kondisi awal pra siklus dalam penelitian ini menunjukkan bahwa ketuntasan belajar peserta didik kelas II SD Negeri Losari Kidul 02 Kecamatan Losari Kabupaten Brebes untuk mata pelajaran IPA materi Sifat-sifat Magnet yang sudah tuntas ada 10 peserta didik (58,7\%) dan yang belum tuntas atau dibawah KKM ada $7(41,1 \%)$ peserta didik, sedangkan target ketuntasan klasikal adalah $88,1 \%$ belum tercapai dan sangat perlu untuk ditindak lanjuti melalui penelitian.

Pada pertemuan pertama peserta didik yang bernilai 100 tidak ada ( $0 \%$ ) yang bernilai 85 ada 2 anak (11,7\%), yang bernilai 80 ada 4 anak (23,5\%), yang bernilai 75 ada 4 anak $(23,5 \%)$, yang nilainya 65 ada 2 anak $(11,7 \%)$. Berikut diagram nilai hasil belajar pada siklus I:

Tabel 1. Persentase Nilai Siklus I

\begin{tabular}{cccccc}
\hline No & Nilai & $\begin{array}{c}\text { Jumlah } \\
\text { Peserta } \\
\text { Didik }\end{array}$ & Jumlah Nilai & Tuntas & $\begin{array}{c}\text { Pelum } \\
\text { Tuntas }\end{array}$ \\
\hline 1 & 30 & 1 & 30 & - & $5,9 \%$ \\
2 & 50 & 1 & 50 & - & $5,9 \%$ \\
3 & 55 & 1 & 55 & - & $5,9 \%$ \\
4 & 60 & 2 & 120 & - & $11,7 \%$ \\
5 & 65 & 2 & 130 & - & $11,7 \%$ \\
6 & 75 & 4 & 300 & $23,5 \%$ & - \\
7 & 80 & 4 & 320 & $23,5 \%$ & - \\
8 & 85 & 2 & 170 & $11,7 \%$ & - \\
\hline & Jumlah & $\mathbf{1 7}$ & $\mathbf{1 1 7 5}$ & $\mathbf{5 8 , 7} \%$ & $\mathbf{4 1 , 1} \%$ \\
\hline
\end{tabular}

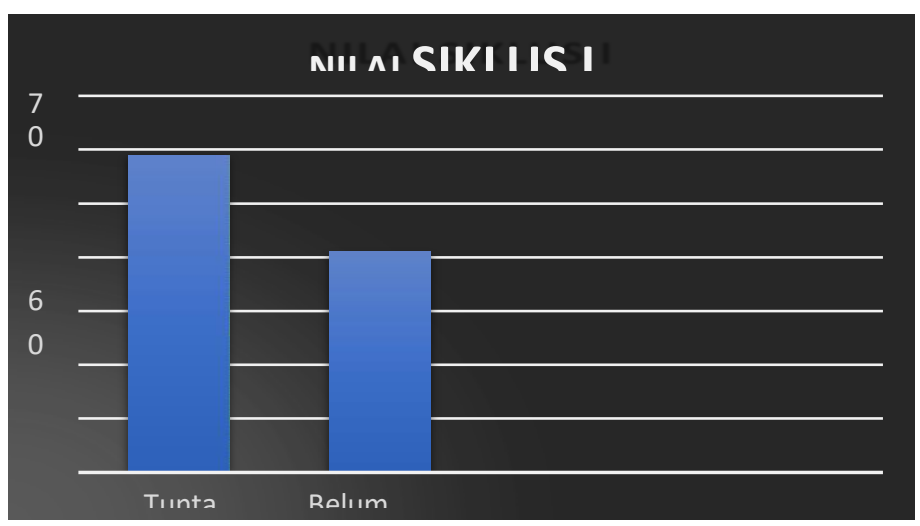

Gambar 1. Diagram Nilai Hasil Belajar Siklus I 
Nilai KKM yang harus diperoleh peserta didik adalah $\geq 70$. Dari hasil pembelajaran siklus I yang telah dilaksanakan oleh 17 peserta didik, nilai yang diraih yaitu 58,7 \% peserta didik yang mendapat nilai lebih dari KKM, dan 41,1\% yang mendapat nilai kurang dari KKM, dengan rata - rata nilai kelas yaitu 69,12. Atas dasar perolehan data tersebut, untuk itu penulis melakukan penguatan perbaikan pada siklus II.

Tabel 2. Persentase Nilai Siklus II

\begin{tabular}{cccccc}
\hline No & Nilai & $\begin{array}{c}\text { Jumlah } \\
\text { Peserta } \\
\text { Didik }\end{array}$ & $\begin{array}{c}\text { Jumlah } \\
\text { Nilai }\end{array}$ & Tuntas & $\begin{array}{c}\text { Prosentase } \\
\text { Belum } \\
\text { Tuntas }\end{array}$ \\
\hline 1 & 60 & 1 & 60 & - & $5,9 \%$ \\
2 & 65 & 1 & 65 & - & $5,9 \%$ \\
3 & 75 & 4 & 300 & $23,5 \%$ & - \\
4 & 80 & 1 & 80 & $5,9 \%$ & - \\
5 & 85 & 5 & 425 & $29,4 \%$ & - \\
6 & 90 & 2 & 180 & $11,7 \%$ & - \\
7 & 95 & 1 & 95 & $5,9 \%$ & - \\
8 & 100 & 2 & 200 & $11,7 \%$ & - \\
\hline & Jumlah & $\mathbf{1 7}$ & $\mathbf{1 4 0 5}$ & $\mathbf{8 8 , 1} \%$ & $\mathbf{1 1 , 8} \%$ \\
\hline
\end{tabular}

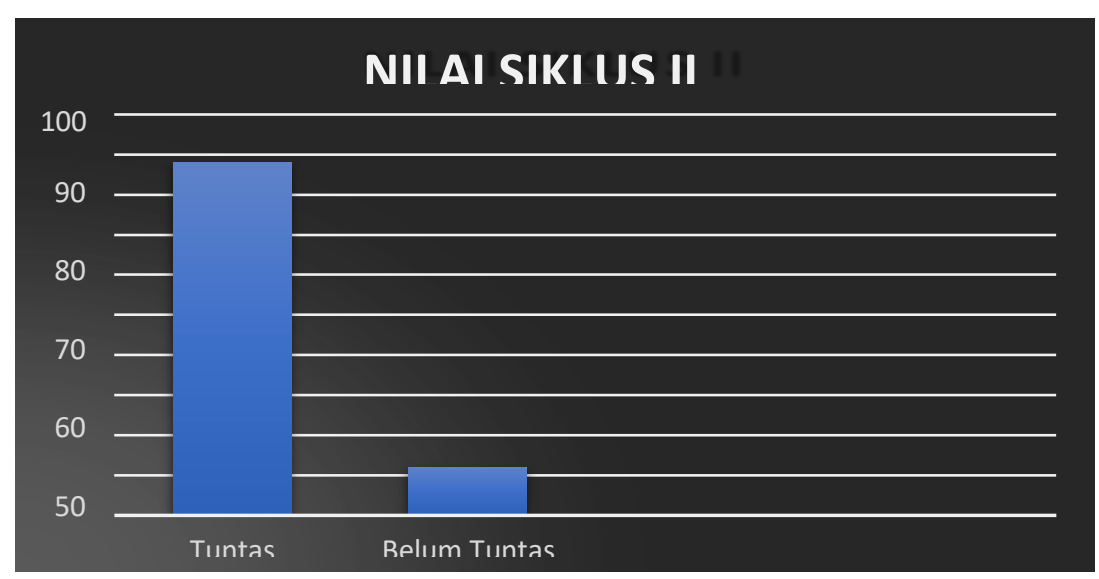

Gambar 2. Diagram Nilai Hasil Belajar Siklus II

Dari hasil penelitian yang telah dilakukan, terlihat ada peningkatan nilai peserta didik mulai dari prasiklus, siklus I dan siklus II pada muatan pelajaran IPA materi Sifatsifat Magnet. Prosentase pencapaian hasil pembelajaran dari mulai siklus I yang lebih dari KKM mencapai 58,7\% atau 10 orang dari 17 peserta didik sedangkan $41,1 \%$ atau 7 dari 17 peserta didik belum tuntas, siklus II mencapai 88,1\% atau 15 orang dari 17 peserta didik, sedangkan $11,8 \%$ atau 2 dari 17 peserta didik belum tunta. Hanya $11,7 \%$ atau 2 orang dari 17 peserta didik yang tidak mengalami peningkatan disebabkan adanya faktor internal dari peserta didik tersebut. Meningkatnyapemahaman peserta didik terhadap materi ini didukung oleh penerapan model pembelajaran Problem Based Learning (PBL) yang diterapkan oleh peneliti. Peserta didik sangat aktif pada saat pembelajaran dilaksanakan sehingga pemahaman peserta didik terhadap materi yang disampaikan meningkat.

Data tersebut diatas menunjukan bahwa dengan penerapan model pembelajaran Problem Based Learning (PBL) dapat meningkatkan Hasil Belajar peserta didik pada mata pelajaran IPA khususnya pada materi Sifat- sifat Magnet, di SD Negeri Losari Kidul 02, Kecamatan Losari, Kabupaten Brebes. 


\section{SIMPULAN}

Dari hasil pembahasan dan perbaikan pembelajaran yang telah dilaksanakan dapat di simpulkan bahwa pemahaman adalah suatu proses, cara memahami dan cara mempelajari dengan baik supaya bertambah pengetahuan yang banyak untuk mencapai tujuan dan hasil belajar. Pemahaman pada peserta didik sangatlah diperlukan terlebih pada mata pelajaran IPA yang menjadi permasalahan penulis pada penelitian yang telah dilaksanakannya.

Dalam merancang tahapan pembelajaran seringkali guru menerapkan sebuah model pembelajaran, penerapannya haruslah sesuai dengan materi yang akan disampaikannya. Karena model pembelajaran adalah aktualisasi dari model belajar yang hakekatnya membantu para peserta didik memperoleh informasi, ide, keterampilan, nilai dan cara berfikir.

Salah satu penerapan model pembelajaran yang digunakan oleh penulis yaitu model pembelajaran Problem Based Learning (PBL). Model pembelajaran ini menerapkan suatu kegiatan yang dilakukan oleh peserta didik dengan cara: Peserta didik dikelompokkan menjadi beberapa kelompok dan bekerja sama dalam pasangan, bertiga atau satu kelompok utuh.

Dari hasil pembelajaran siklus II yang telah dilaksanakan oleh 17 peserta didik, terdapat peningkatan nilai yang diraih yaitu $88,1 \%$ peserta didik yang mendapat nilai lebih dari KKM dan $11,8 \%$ yang mendapat nilai kurang dari $\mathrm{KKM}$, dengan rata - rata nilai kelas 82,64 . Atas dasar perolehan data tersebut prosentase nilai peserta didik naik secara signifikan.

\section{DAFTAR PUSTAKA}

Hamalik, Oemar. (2001). Proses Belajar Mengajar. Jakarta : Bumi Aksara.

Ngalimun, Fauzani, Salabi Ahmad. (2015). Strategi dan Model Pembelajaran.Yogyakarta : Aswajapressindo.

Hamdani. (2011). Strategi Belajar Mengajar. Bandung: Pustaka Setia.

Lestari, Nyoman Sri. Pengaruh model pembelajran berbasis masalah (Problem Based Learning) dan motivasi belajar terhadap prestasi belajar fisika bagi siswa IPA disekolah dasar. Jurnal Penelitian Pendidikan kelas VII SMP. http://119.252.161.254/ejournal/index.php/jurnal_tp/article/view/297/91. Hal 15.

Skujur, B Solikhin. Pengaruh Based Learning terhadap motivasi belajar dan hasil belajr siswa smk.https://journal.uny.ac.id/index.php/jpv/article/view/1043/844. Hal 371.

Suharsimi, Suhardjono dan Supardi. (2008). Penelitian Tindakan Kelas. Jakarta: PT. Bumi Aksara.

Sulipan.(2008). Penelitian Tindakan Kelas. diambil dari http://www.profesiguru.com/pdf/penelitian\%20tindakan\%20kelassiln\%20dan\%2 Okti.pdf. tanggal 19 Oktober 2020

Sunaryo, Soenarto. (2018). Penelitian Tindakan Kelas. diambil dari http://staffnew.uny.ac.id/upload/131568300/lainlain/PENELITIAN+TIN DAKAN+KELAS.pdf. tanggal 19 Oktober 2020.

Sunendar, Tatang. (2008). Penelitian Tindakan Kelas (Part II). diambil dari http://www.akhmadsudrajat.wordpress.com/2008/03/21/penelitian-tindakankelas-part-ii. tanggal 19 Oktober 2020.

Suwarsih Madya. (2008). Penelitian Tindakan Kelas (Bagian III). diambil dari http://www.ktiguru.org/index.php/ptk-3/part-iii. tanggal 19 Oktober 2020.

V.Sutrisno dkk.(2011).IImu Pengetahuan Alam Aktif Kelas 6. Sidoarjo: PT Masmedia Buana Pustaka. 
SHEs: Conference Series 3 (4) (2020) 262- 267

Wulandari. Pengaruh Problem Based Learning terhadap hasil belajar ditinjau dari motivasi belajar plc di SMK. https://journal.uny.ac.idindex.php/jpv/article/view/1600/1333. Hal 182. 